2017

\title{
North Atlantic Rhodolith Beds
}

\author{
Hernandez-Kantun, JJ
}

http://hdl.handle.net/10026.1/8444

10.1007/978-3-319-29315-8_10

Coastal Research Library

Springer

All content in PEARL is protected by copyright law. Author manuscripts are made available in accordance with publisher policies. Please cite only the published version using the details provided on the item record or document. In the absence of an open licence (e.g. Creative Commons), permissions for further reuse of content should be sought from the publisher or author. 
This is the author's accepted manuscript. The final published version of this work (the version of record) was published in 2017 by Springer in the book entitled «Rhodolith/Maërl Beds: A Global Perspective» (edited by Rafael Riosmena-Rodriguez, Wendy Nelson and Julio Aguirre) available at: DOI 10.1007/978-3-319-29315-8. This work is made available online in accordance with the publisher's policies. Please refer to any applicable terms of use of the publisher.

\title{
Chapter 10. North Atlantic Rhodolith Beds
}

Jazmin J. Hernandez-Kantun, Jason M. Hall-Spencer, Jacques Grall, Walter Adey, Fabio Rindi, Christine A. Maggs, Ignacio Bárbara and Viviana Peña.

\begin{abstract}
Beds of coralline algal sediment form ecologically and economically important habitats in the North Atlantic. These habitats can occur from the intertidal down to $60 \mathrm{~m}$ depth, and they are locally abundant in several countries. Fourteen species of coralline algae form rhodoliths or maerl in this region; Lithothamnion corallioides, $L$. glaciale, L. tophiforme and Phymatolithon calcareum are the most widely recorded. The structure and biodiversity of these habitats is destroyed by dredging and can be degraded by towed demersal fishing gear and by mussel and salmon farming. Legislation has been
\end{abstract}


passed in the Eropean Union (EU) to protect $P$. calcareum and $L$. corallioides which should be extended to include the other maerl species from the region. Outside the EU there is a lack of baseline information concerning the importance of these habitats: a fuller understanding of their role may lead to protection in Scandinavia, Iceland and the Atlantic coasts of Canada and the United States. The design of such protected areas would need to consider the ongoing effects of invasive species, ocean warming and acidification.

Jazmin J. Hernandez-Kantun

National Museum of Natural History, Smithsonian Institution, Washington, D.C. and Irish Seaweed Research Group, Ryan Institute, National University of Ireland Galway, Ireland. Corresponding author:jaz1083@gmail.com Jason M Hall-Spencer

Marine Biology and Ecology Research Centre, Plymouth University, PL4 8AA, UK, jason.hall-spencer@plymouth.ac.uk, Jacques Grall 
Séries Faune-Flore, Observatoire UMS 3113, Institut universitaire

Européen de la Mer, F-29280 Plouzane, France,

Jacques.grall@univ-brest.fr

Walter Adey

Botany Department, National Museum of Natural History, Smithsonian Institution, Washington, D.C, adeyw@si.edu

Fabio Rindi

Dipartimento di Scienze della Vita e dell'Ambiente, Università

Politecnica delle Marche, Via Brecce Bianche, 60131 Ancona, Italy, f.rindi@univpm.it

Christine A. Maggs

School of Biological Sciences, The Queen's University of Belfast, 97 Lisburn Road, Belfast BT9 7BL, Northern Ireland,

c.maggs@qub.ac.uk

Ignacio Bárbara

Grupo de investigación BIOCOST, University of A Coruña, Spain, barbara@udc.es

Viviana Peña. 
Grupo de investigación BIOCOST, University of A Coruña, Spain; UMR 7138 Systématique, Adaptation et Evolution. Muséum National d'Histoire Naturelle (MNHN), France; Phycology Research Group, Ghent University, Belgium, vpena@udc.es.

\subsection{Introduction}

Aggregations of living unattached corallines, previously often referred to as nodules, were given the name rhodoliths by Bosselini \& Ginsberg (1971). Adey \& MacIntyre (1973) provided an early discussion of their genesis and distribution. Such aggregations have long been known as maerl in the North East Atlantic, a Breton term for unattached thalli that lack a shell or pebble core (Irvine \& Chamberlain 1994). Here, we provide an overview of rhodolith/maerl occurrence in the colder waters of the North Atlantic and summarize the distribution, species composition, biodiversity and ecological importance of these habitats. We include the eastern coasts of Canada and the United States north of Cape Hatteras plus Greenland, Iceland, Europe and Macaronesia (Azores, Madeira and Canary Islands). . 


\subsection{Distribution and species composition}

Unattached coralline algal beds occur on open coasts, in tideswept channels and in sheltered areas with weak currents, from the intertidal to $60 \mathrm{~m}$ depth with the deepest records found in Svalbard and Macaronesia (Cabioch 1974, Alfonso-Carrillo \& Gil-Rodríguez 1982, Hall-Spencer et al. 2010, Teichert et al. 2012). These habitats are particularly abundant in Scotland, Ireland and Brittany (De Grave et al. 2000, Hall-Spencer et al. 2010) and in Newfoundland and Labrador (Adey \& MacIntyre 1973). The more northern beds are less well known but existing literature indicates that these habitats may be important and extensive at high latitudes (Foslie 1895, Adey 1968, Sneli 1968, Gunnarsson 1977, Freiwald 1995, Teichert et al. 2012).

Many species of crustose coralline algae can continue to survive unattached in appropriate environmental conditions. However, fewer species commonly form rhodoliths or maerl. For example, Lithothamnion lemoineae forms thick crusts in the North Atlantic subarctic that can become detached but rarely survive as rhodoliths. 
In contrast, Clathromorphum compactum occasionally forms rhodolith beds in the Subarctic coating pebbles in narrow island passages with strong currents.

The North Atlantic harbours fourteen rhodolith/maerl-forming species of coralline algae (Table 11.1; Pardo et al., submitted). The four most widely recorded species are Lithothamnion corallioides, L. glaciale, L. tophiforme and Phymatolithon calcareum (Fig. 11.1). These four species have been exhaustively researched in the North Atlantic to find reliable identification features; Adey \& McKibbin (1970), Irvine \& Chamberlain (1994), Adey et al. (2005) and Teicher et al. (2012). In the northwestern Atlantic, Lithothamnion glaciale and Lithothamnion tophiforme occupy different, overlapping ecological niches. L. glaciale is particularly widespread, ranging from the intertidal pools to moderately deep water and from highly exposed to protected shorelines in Subarctic and Boreal Regions (Adey 1966). In contrast, L. tophiforme is more abundant in Arctic and deeper (25-39 m) waters (Adey et al. 2005). On the Labrador Coast, the two species typically occur together at 20-25 m. Leptophytum foecundum, in its rhodolith state, is colder Subarctic to 
Arctic in distribution and occurs primarily in shell and pebble beds in strong current zones. The cores of this species are usually pebbles or dead mollusc shell.

Currently, efforts are being made to understand the diversity of rhodolith-forming corallines in the North Atlantic area using molecular techniques (Peña et al. 2014). This approach has led to the recent description of Mesophyllum sphaericum which forms maerl in the NE Atlantic (Peña et al. 2011). The use of DNA sequences from type material will continue to improve the taxonomy of this group (Peña et al. 2014). Species of North Atlantic Lithophyllum will require considerable taxonomic work as there appear to be cryptic species, problems with the features used to separate species and the widespread use of incorrect names (Irvine \& Chamberlain 1994).In the north Atlantic Lithophyllum rarely contribute to maerl beds but at a few sites, such as Mannin Bay and Kingstown Bay (Ireland) and the Bay of Brest (France), species traditionally called L. dentatum and L. fasciculatum can be abundant (Cabioch 1968, Hall-Spencer et al. 2010). 
The colder parts of the North Atlantic Ocean comprise four biogeographic regions: Arctic; Subarctic; Boreal (Celtic) and Lusitanean (Adey \& Steneck, 2001, Adey \& Hayek 2011). The Subarctic Region transitions with the Boreal Region primarily in southern Iceland, the Norwegian Coast and to a lesser extent in northwestern Scotland. The North Atlantic Subarctic Region (NW Atlantic, S. Greenland and Spitzbergen and northern Iceland) as a Pleistocene, glacially-restricted outlier of the North Pacific Subarctic is relatively depauperate in seaweeds (Adey et al. 2008, Maggs et al. 2008), while the overlapping Boreal and Lusitanian Regions are relatively rich in seaweed species. Likewise, the number of species of coralline algae forming beds of rhodolith or maerl is higher in European coastal Boreal/Lusitanean regions than the Subarctic Coasts. Further studies to uncover any hidden species diversity are needed to fully clarify these relationships and to understand evolutionary patterns (Aguirre et al. 2000).

\subsection{Biodiversity and ecology}


Unattached coralline algae produce banks of carbonate rich sediments that trap suspended particulates and infaunal faeces to build complex habitats that can be 1000s of years old (Grall \& HallSpencer, 2003). They can also provide sediments for current transport to adjacent marine habitats (Farrow et al. 1978, Bosence $1979,1980)$ and to coasts where carbonate sand dunes are important habitats for terrestrial organisms (Birkett et al. 1998a).

Rhodoliths and maerl are formed by coralline algae with relatively slow growth rates and a perennial life strategy; some thalli can live >100 years (Bosence 1983, Potin et al. 1990, Foster 2001, Blake \& Maggs 2003, Bosence \& Wilson 2003, Frantz et al. 2005). Many rhodoliths begin as crusts growing on rock; they break free from the substratum due to invertebrate boring and/or wave action and bioturbation, and continue growing unattached on surrounding or deeper sedimentary bottoms (Adey \& MacIntyre 1973, Adey \& Hayek 2011). Thallus fragmentation is the major mechanism of propagation of rhodolith beds (Bosence 1976, Johansen 1981). Coralline algae can accumulate in large beds with a three-dimensional matrix that provides a wide range of ecological niches (Bosence 1983, Birkett et 
al. 1998a, Hall-Spencer 1998, Barberá et al. 2004, Grall et al. 2006, Hinojosa-Arango et al. 2009).

These habitats have considerable ecological significance due to the high diversity of associated organisms (Fig. 11.2). There have been numerous studies of the associated flora and fauna of NE Atlantic beds ( Cabioch, 1969, Keegan 1974, Bosence 1979, 1980, Maggs 1983a,b, Hall-Spencer 1998, BIOMAERL Team 1999, HallSpencer \& Atkinson 1999, Barbéra et al. (2004), Kamenos et al. 2004a,b,c, Hinojosa-Arango et al. 2009, Peña \& Bárbara 2008a,b, 2010a,b, 2013, Peña 2010, Teichert et al. 2012, Scottish MPA Project 2013). In contrast, the number of studies available for the northwestern Atlantic is more limited: two studies in Canada include investigations on fish of rhodolith beds by Kulka et al. (2004) and the epi- and in-fauna by Gagnon et al. (2012).

A review of the associated flora of NE Atlantic rhodolith beds (Peña et al. submitted) reported a total of 349 algal species, which is around $30 \%$ of the total seaweed diversity in this region. The most diverse beds (150-257 seaweed species) occur in the temperate regions with $25-42 \%$ of the total seaweed diversity recorded in the 
area. The flora of northern rhodolith beds (Iceland, Scandinavia) is less diverse but has not been studied in detail. The associated flora increases the heterogeneity and complexity of the habitat due to the presence of a wide range of algal morphologies, ranging from endolithic and crustose forms to large kelp. The associated flora of temperate NE Atlantic rhodolith beds is seasonal with a peak of diversity in the spring-summer period (Cabioch 1969, Maggs 1983a, Bárbara et al. 2004, Grall et al. 2006, Peña \& Bárbara 2010a). Species with heteromorphic life-histories and crustose sporophyte phases are particularly abundant (Maggs \& Guiry 1989, Peña \& Bárbara 2010b). The presence of some algal species is largely confined to rhodolith beds, such as the Rhodophyta Gelidiella calcicola, Cruoria cruoriaeformis, Gelidium maggsiae and Halymenia latifolia and the Chlorophyta Cladophora rhodolithicola (Cabioch 1969, Maggs 1983, Maggs \& Guiry 1987, 1989, Rico \& Guiry 1997, Bárbara et al. 2004, Grall et al. 2006, Leliaert et al. 2009, Peña \& Bárbara 2010a,b, 2013).

The BIOMAERL project revealed 556 animal taxa associated with NE Atlantic maerl beds: 10 Porifera, 35 Cnidaria, 174 Annelida, 137 
Crustacea, 138 Mollusca, 26 Echinodermata, 22 Bryozoa, 11 Ascidiacea, and 32 Pisces taxa (Barberá et al. 2004). A ten year survey of nine maerl beds in Brittany lists 1,204 fauna species, including 295 Annelida, 290 Arthropoda, 207 Mollusca, 35 Echinodermata, and 377 species of other phyla (Grall unpublished).

The three-dimensional matrix of coralline algal sediments enhances their biodiversity (Bosence 1979); this is evident when their diversity is compared with surrounding habitats; kelp forests harbour around $10 \%$ fewer species of the NE Atlantic flora, seagrasses host around 5\% fewer species, and muddy and sand banks harbour 30 to $50 \%$ fewer species than adjacent maerl beds (Whelan \& Cullinane 1985, Shultze et al. 1990, Davison \& Hughes 1998, Birkett et al. 1998b, Grall 2002, Otero-Schmitt \& Pérez-Cirera 2002, Johnson et al. 2005). Maerl beds also provide brood strock areas for commercially important bivalves, such as scallops, as well as nursery areas for juvenile fish such as cod (Hall-Spencer et al. 2003, Kamenos \& Moore 2004, Kamenos et al. 2004a,b,c). In the northwestern Atlantic, rhodolith beds of Lithothamnion typically support abundant scallops, (Aequipecten irradians) which are commercially harvested. 


\subsection{Conservation status}

In the North Atlantic, coralline algal sediments are dredged for use as a fertilizer on acidic soils, as a food additive for animals and humans, in water treatment filters and in cosmetics (Blunden et al. 1981, De Grave \& Whitaker 1999, Foster 2001, Grall \& Hall-Spencer 2003,Emerton \& Choi 2008). This dredging of biodiverse nursery grounds is widely considered to be environmentally unsustainable (Barberá et al. 2003) and has ceased in the United Kingdom.

Although not as devastating as dredging, European maerl beds have also been impacted by aquaculture (Hall-Spencer et al. 2006, Hall-Spencer \& Bamber 2007, Peña \& Bárbara 2008a, Peña 2010), changes in current patterns associated with construction (Birkett et al. 1998a, Grall \& Hall-Spencer 2003), dredge fisheries (Hall-Spencer 1998, Hall-Spencer \& Moore 2000, Hall-Spencer et al. 2003, Hauton et al. 2003, Kamenos et al. 2003), as well as increased sedimentation and eutrophication (Hily et al. 1992, Grall \& Glemarec 1997). There is also a growing realisation that these habitats may be especially vulnerable to ocean acidification since the high $\mathrm{Mg}$-calcite skeletons of coralline algae dissolve easily as $\mathrm{CO}_{2}$ levels 
rise(Nelson 2009, Büdenbender et al. 2011, Porzio et al. 2011, DíazPulido et al. 2012, Noisette et al. 2013, see Chapter XX by Martin \& Hall-Spencer).

Indirect effects to NE Atlantic maerl beds arise due to the spread of invasive species such as the gastropod Crepidula fornicata the Rhodophyta Antithamnionella spirographidis, A. ternifolia, Bonnemaisonia hamifera, Dasya sessilis, Grateloupia turuturu, Heterosiphonia japonica and Neosiphonia harveyi, the Heterokontophyta Colpomenia peregrina, Sargassum muticum and Undaria pinnatifida, and the Chlorophyta Codium fragile (Grall \& Hall-Spencer 2003, Pena et al. submitted).. Only though monitoring will we be able to detect ecological changes to these habitats (BIOMAERL Team 1999, Birkett et al. 1998a).

Research efforts have been made to understand the effects of physical factors on rhodolith-forming species in the North Atlantic, including the effect of temperature (Adey \& McKibbin 1970, Blake \& Maggs 2003, Wilson et al. 2004, Kamenos et al. 2008, Kamenos 2010, Kamenos \& Law 2010); the influence of light (Adey 1970, Adey \& McKibbin 1970, Adey \& Macintyre 1973, Wilson et al. 
2004, Rix et al. 2012, Teichert et al 2013); the biological response of organic matter/burial (Wilson et al. 2004, Blake et al. 2007, Rix et al. 2012); the response of heavy metal contamination (Wilson et al. 2004) and the influence of ocean acidification (Hall-Spencer et al. 2006, Büdenbender et al. 2011, Burdett et al. 2012, Ragazzola et al. 2013, Noisette et al. 2013).

Many of these studies confirmed the negative effect of ocean acidification, rise of temperature and burial on the physiology of rhodolith-forming species, suggesting that a combination of physical stressors can affect coralline species and the flora and fauna assemblages associated with them. Also, the negative effects on the rhodolith bed structure and disturbance and loss of diversity of the associated flora and fauna has been documented, mostly due to anthropogenic activities such as bivalve fishing and aquaculture (BIOMAERL Team 1999, Bárbera et al. 2003, Hall-Spencer et al. 2003, 2006, Hall-Spencer \& Bamber 2007, Peña \& Bárbara 2008a, Peña 2010). Apart from the decrease in the cover and thickness of the living maerl layer, a decrease in maerl size was observed in Galician beds impacted by mussel aquaculture (Peña 2010). 
The EU Habitats Directive (92/43/EEC) includes maerl and lists Lithothamnion corallioides and Phymatolithon calcareum for protection. Maerl beds are also included in the list of threatened habitats within the NE Atlantic due to multiple threats from anthropogenic activities, high sensitivity and low recovery capacity (OSPAR 2006).

Many areas of maerl are now included within areas that are listed as protected areas; in NW Spain for example 28\% of known maerl beds are located within protected areas with another 19 unprotected maerl beds proposed for future conservation actions (Peña \& Bárbara 2006, 2009).

There are still information gaps concerning the biological and ecological characteristics of maerl assemblages in Europe. Information on reproduction, size, distribution and diversity of coralline algae forming maerl beds is necessary to improve management of these habitats(OSPAR 2006). Barberá et al. (2004) suggested that maerl beds should be recognized as a specific habitat in the EU Habitats Directive and that the full range of maerl-forming species should be listed for conservation purposes otherwise the rarest types 
of maerl bed may not be given the high conservation status they require.

The development of newer methodologies for the characterization of maerl beds was also recommended by the Census of Marine Life project Natural Geography In Shore Areas (NaGISA, Www.coml.org). A standardized methodology is required to monitor maerl beds in space and time for features such as reproductive effort, kind of reproduction, size, distribution, and diversity of coralline algae forming the habitat (Steller et al. 2007). Examination of these features can help to assess patterns typical of "pristine" vs "impacted" maerl beds in time (past vs present) and space (different beds located at distance of $\mathrm{km}$, tens of $\mathrm{km}$ or hundreds of $\mathrm{km}$ ) and can be used to evaluate the health of the habitats.

\subsection{Conclusion}

The four coralline algal species that most commonly grow unattached in the North Atlantic have been studied intensively in Europe but detailed information on the status and ecology of these habitats is lacking from the USA, Canada, Greenland and Iceland. There 
is a lack of long-term monitoring of these wonderful habitats

throughouth the North Atlantic which is a priority for management of these productive coastal systems. The activities that are most damaging for these habitats are now well known; the next steps are to raise awareness, enforce conservation legisloation and promote sensible stewardship of these highly diverse habitats.

Acknowledgements

JHK acknowledges support from CONACyt-Mexico, SEP-Mexico, Smithsonian Institution-USA and National University of Ireland, Galway. Studies on the Iberian Peninsula were supported by the research projects CGL2006-03576/BOS (Ministerio de Educacion y Ciencia and FEDER) and PGIDIT03PXIB10301PR (Xunta de Galicia). VP acknowledges support by Xunta de Galicia (Plan Galego de Investigación, Innovación e Crecemento, Plan I2C, 2011-2015). JHS acknowledges support from the EU 'Mediterranean Sea Acidification under a changing climate' project (MedSeA; grant agreement 265103). 


\section{References}

Adey WH (1966) Distribution of saxicolous crustose corallines in the northwestern North Atlantic. J Phycol 2:49-54

Adey WH (1968) The distribution of crustose Corallines on the Icelandic coast. Science in Iceland 1:16-25

Adey WH (1970) The effects of light and temperature on growth rates in boreal-subarctic crustose corallines. J Phycol 6:269276

Adey WH (1971) The sublittoral distribution of crustose corallines on the Norwegian coast. Sarsia 46:41-58

Adey WH, Adey PJ (1973) Studies of the biosystematics and ecology of the epilithic crustose Corallinaceae of the British Isles. Brit Phycol J 8:343-407

Adey WH, Chamberlain YM, Irvine LM (2005) An SEM-based analysis of the morphology, anatomy and reproduction of Lithothamnion tophiforme (Esper) Unger (Corallinales, Rhodophyta), with a comparative study of associated North Atlantic Arctic/Subarctic Melobesioideae. J Phycol 41:10101024 
Adey WH, Hayek L-AC (2011) Elucidating Marine Biogeography with Macrophytes: Quantitative Analysis of the North Atlantic Supports the Thermogeographic Model and Demonstrates a Distinct Subarctic Region in the Northwestern Atlantic. Northeastern Naturalist 18: monograph 8: 1-128

Adey WH, Lindstorm SC, Hommersand MH, Muller KM (2008) The biogeographic origin of arctic endemic seaweeds: a thermogeographic view. J Phycol 44:1384-1394.

Adey WH, MacIntyre IG (1973) Crustose coralline algae: a re-evaluation in the geological sciences. Geo Soc Am Bull 84:883904

Adey WH, McKibbin DL (1970) Studies on the maërl species Phymatolithon calcareum (Pallas) nov. comb. and Lithothamnium corallioides Crouan in the Ria de Vigo. Bot Mar 13:100-06

Adey WH, Steneck, RS (2001). Thermogeography over time creates biogeographic regions: a temperature/space/time-integrated model and an abundance-weighted test for benthic marine algae. Journal of Phycology 37:677-698. 
Aguirre J, Riding R, Braga JC, (2000). Diversity of coralline red algae: origination and extinction patterns from the Early Cretaceous to the Pleistocene. Paleobiology 26:651-667

Alfonso-Carrillo J, Gil-Rodríguez MC (1982) Sobre la presencia de un fondo de "Maerl" en las Islas Canarias. Collectanea Botanica 13:703-708

Athanasiadis A (1996) Taxonomisk litteratur och biogeografi av Skandinaviska rödalger och brunalger. Göteborg: Algologia.

Bárbara I, Cremades J, Veiga AJ (2004) Floristic study of a maërl and gravel subtidal bed in the Ría de Arousa (Galicia, Spain). Bot Complutensis 28:27-37

Barberá C, Bordehore C, Borg JA, Glémarec M, Grall J, Hall- Spencer JM, De La Huz Ch, Lanfranco E, Lastra M, Moore PG, Mora J, Pita ME, Ramos- Esplá AA, Rizzo R, SánchezMata A, Seva A, Schembri PJ, Valle C (2004) Conservation and management of northeast Atlantic and Mediterranean maerl beds. Aquat Conserv 13:S65-S76

BIOMAERL Team (1999) Final Report, BIOMAERL project (Coordinator: Moore PG, University Marine Biological Station Millport, Scotland), EC Contract No. MAS3-CT95-0020, 1: 
1-541, 2: 542-973 pp. + Appendix.

Birkett DA, Maggs CA, Dring MJ (1998a) Maerl (Volume V). An overview of dynamics and sensitivity characteristics for conservation management of marine SACs. Acottish Association for Marine Science. (UK Marine SACs Project).

Birkett DA, Maggs CA, Dring MJ, Boaden PJS (1998b) Infralittoral reef biotopes with kelp species. An overview of dynamic and sensitivity characteristics for conservation management of marine SACs. Scott. Assoc. Mar. Sci (UK Marine SACs Project).

Blake C, Maggs CA (2003) Comparative growth rates and internal banding periodicity of maerl species (Corallinales, Rhodophyta) from northern Europe. Phycologia 42:606-612

Blake C, Maggs CA, Reimer P (2007) Use of radiocarbon dating to interpret past enviroments of maerl beds. Cienc Mar 33:385397

Blunden G, Farnham WF, Jephson N, Barwell CJ, Fenn RH, Plunkett BA (1981) The composition of maërl beds of economic interest in northern Brittany, Cornwall and Ireland. In: 
Levring T (ed) Proceedings 10th International Seaweed Symposium. De Gruyter, Berlin

Bosselini A, Ginsberg RN (1971) Form and intertidal structure of recent algal nodules (rhodolites) from Bermuda. J Geol 79:669-682

Bosence DWJ (1976) Ecological studies on two unattached coralline algae from western Ireland. Palaeontology 19:365-395

Bosence DWJ (1979) Live and dead faunas from coralline algal gravels, Co.Galway. Palaentology 22:449-78

Bosence DWJ (1980) Sedimentary facies, production rates and facies models for recent coralline algal gravels, Co. Galway, Ireland. Geol J 15:91-111

Bosence DWJ (1983) Descriptions and classification of rhodoliths (rhodoids, rhodolites). In: Peryt TM (ed) Coated Grains. Springer-Verlag, Berlin

Bosence DWJ, Wilson J (2003) Maerl growth, carbonate production rates and accumulation rates in the northeast Atlantic. Aquat Conserv 13:S21-S31 
Büdenbender J, Riebesell U, Form A (2011) Calcification of the Artic coralline red algae Lithothamnion glaciale in response to elevated $\mathrm{CO}_{2}$. Mar Ecol Prog Ser 441:79-87

Burdett H, Aloisio E, Calosi P, Findlay HS, Widdicombe S, Hatton AD, Kamenos NA (2012) The effect of chronic and acute low $\mathrm{pH}$ on the intracellular DMSP production and epithelial cell morphology of red coralline algae. Mar Biol Res 8:756763

Cabioch J (1968) Quelques particularités anatomiques du Lithophyllum fasciculatum (Lamarck) Foslie. Bulletin de la Société botanique de France 115:173-186

Cabioch J (1969) Les fonds de maërl de la Baie de Morlaix et leur peupplement vegetal. Cah Biol Mar 10:139-61

Cabioch J (1974) Un fond de maerl de l'Archipel de Madère et son peuplement végétal. Bulletin de la Société Phycologique de la France 19:74-82

Davison DM, Hughes DJ (1998) Zostera Biotopes (volume I). An overview of dynamics and sensitivity characteristics for conservation management of marine SACs. Scottish Association for Marine Science (UK Marine SACs Project) 
De Grave S, Fazakerley H, Kelly L, Guiry MD, Ryan M, Walshe J (2000) A study of selected maërl beds in Irish waters and their potential for sustainable extraction. Marine Resource Series (Ireland) 10:1-44

De Grave S, Whitaker A (1999) A census of maërl beds in Irish waters. Aquat Conserv 9:303-11.

Diaz-Pulido G, Anthony KRN, Kline DI, Dove S, Hoegh-Guldberg O (2012) Interactions between ocean acidification and warming on the mortality and dissolution of coralline algae. J Phy$\operatorname{col} 48: 32-39$

Emerton V, Choi E (ed) (2008) Essential guide to food additives. Leatherhead Food International Ltd, UK

Farrow GE, Cucci M, Scoffin TP (1978) Calcareous sediments on the nearshore continental shelf of western Scotland. P Roy Soc Edinb B 76:55-76

Foslie M (1895) The Norwegian forms of Lithothamnion. Kongelige Norske Videnskabers Selskabs Skrifter 1894:29-208

Foslie M (1899) Some new or critical lithothamnia. Det Kongelige Norske Videnskabers Selskabs Skrifter 1898:1-19 
Foslie M (1905) Remarks on northern lithothamnia. Det Kongelige Norske Videnskabers Selskabs Skrifter 1905:1-138

Foster MS (2001) Rhodoliths: between rocks and soft places. J Phycol 37:659-667

Frantz BR, Foster MS, Riosmena-Rodriguez R (2005)

Clathromorphum nereostratum (Corallinales, Rhodophyta): The oldest alga? J Phycol 41:770-773

Freiwald A (1995) Sedimentological and biological aspects in the formation of branched rhodoliths in northern Norway. Beiträge zur Paläontologie Österreichs 20:7-19

Gagnon P, Matheson K, Stapleton M (2012) Variation in rhodolith morphology and biogenic potential of newly discovered rhodolith beds in Newfoundland and Labrador (Canada). Bot Mar 55:85-99

Grall J, Glemarec M (1997) Biodiversité des fonds de maerl en Bretagne: Approche fonctionelle et impacts anthropiques. Vie et Milieu 47:339-49

Grall J, Hall-Spencer JM (2003) Problems facing maerl conservation in Brittany. Aquat Conserv 13:S55-S64 
Grall J, Le Loch F, Guyonnet B, Riera P (2006) Community structure and food web based on stable isotopes $(\delta 15 \mathrm{~N}$ and $\delta 13 \mathrm{C})$ analysis of a North Eastern Atlantic maerl bed. J Exp Mar Biol Ecol 338:1-15

Gunnarsson K (1977) Borugar a koralsetlogum i Amarfirdi, Hafransoknir 10:3-10

Hall-Spencer JM (1998) Conservation issues relating to maerl beds as habitats for molluscs. J Conchol Special Publication $2: 271-85$

Hall-Spencer JM, Atkinson RJA (1999) Upogebia deltaura (Crustacea: Thalassinidea) in Clyde Sea maerl beds, Scotland. J Mar Biol Ass UK 79:871-880

Hall-Spencer JM, Bamber R (2007) Effects of salmon farming on benthic Crustacea. Cienc Mar 33:353-366

Hall-Spencer JM, Grall J, Moore PG, Atkinson RJA (2003) Bivalve fishing and maerl-bed conservation in France and the UK retrospect and prospect. Aquat Conserv 13:S33-S41

Hall-Spencer JM, Kelly J, Maggs CA (2010) Background Document for maerl beds. OSPAR commission 
Hall-Spencer JM, Moore PG (2000) Scallop dredging has profound, long-term impacts on maerl habitats. ICES J Mar Sci $57: 1407-1415$

Hall-Spencer JM, White N, Gillespie G, Gillham K, Foggo A (2006) Impact of fish farms on maerl beds in strongly tidal areas. Mar Ecol Prog Ser 326:1-9

Hauton C, Hall-Spencer JM, Moore PG (2003) An experimental study of the ecological impacts of hydraulic bivalve dredging on maerl. ICES J Mar Sci 60:381-392

Hily C, Potin P, Floch JY (1992) Structure of subtidal algal assemblages on soft-bottom sediments: fauna/flora interactions and role of disturbances in the Bay of Brest, France. Mar Ecol Prog Ser 85:115-30

Hinojosa-Arango G, Maggs C, Johnson M (2009) Like a rolling stone: the mobility of maërl (Corallinaceae) and the neutrality of the associated assemblages. Ecology 90:517-28

Irvine LM, Chamberlain YM (1994) Seaweeds of the British Isles. Volume 1 Rhodophyta Part 2B Corallinales, Hildenbrandiales. HMSO, London 
Johansen, H.W. (1981) Coralline Algae, A First Synthesis. CRC publishing USA, Florida

Johnson MP, Edwards M, Bunker F, Maggs C (2005) Algal epiphytes of Zostera marina: Variation in assemblage structure from individual leaves to regional scale. Aquat Bot 82:12-26

Kamenos NA (2010) North Atlantic summers have warmed more than winters since 1353, and the response of marine zooplankton. Proc Natl Acad Sci USA 107:22442-22447

Kamenos NA, Cusack M, Moore PG (2008) Coralline algae are global palaeothermometers with bi-weekly resolution. Geochim Cosmochim ac 72:771-779

Kamenos NA, Law A (2010) Temperature controls on coralline algal skeletal growth. J Phycol 46:331-335

Kamenos NA, Moore PG (2004) Maerl grounds provide both refuge and high growth potential for juvenile queen scallops (Aequipecten opercularis L). J Exp Mar Biol Ecol 313:241254

Kamenos NA, Moore PG, Hall-Spencer JM (2003) Substratum heterogeneity of dredged vs un-dredged maerl grounds. J Mar Biol Ass UK 83:411-413 
Kamenos NA, Moore PG, Hall-Spencer JM (2004a) Small-scale distribution of juvenile dadoids in shallow inshore waters; what role does maerl play? ICES J Mar Sci 61:422-429

Kamenos NA, Moore PG, Hall-Spencer JM (2004b) Nursery-area function of maërl grounds for juvenile queen scallops Aequipecten opercularis and other invertebrates. Mar Ecol Prog Ser 274:183-9

Kamenos NA, Moore PG, Hall-Spencer JM (2004c) Attachment of the juvenile queen scallop (Aequipecten opercularis (L) to maerl in mesocosm conditions; juvenile hábitat selection. J Exp Mar Biol Ecol 306:139-155

Keegan BF (1974) The macrofauna of maërl substrates on the West Coast of Ireland. Cah Biol Mar 15:513-30

Kulka DW, Simpson MR, Hooper RG (2004) Changes in distribution and habitat associations of Wolffish (Anarhichidae) in the Grand Banks and Labrador Shelf. Research document for the Canadian Science Advisory Secretariat. 
Leliaert F, Boedeker C, Peña V, Bunker F, Verbruggen H, De Clerck O (2009) Cladophora rhodolithicola sp. nov. (Cladophorales, Chlorophyta), a diminutive species from European maerl beds. Eur J Phycol 44:155-169

Lemoine M (1910) Repartition et mode de vie du maërl (Lithothamnium calcareum) aux environs de Concarneau (Finistere). Annals de L'institut Oceanographique, Monaco 1(3):128

Maggs CA (1983a) Seasonal study of seaweed communities on subtidal maerl (unattached coralline algae) in Galway Bay, Ireland. Progress in Underwater Science 9:27-40.

Maggs CA (1983b) A phenological study of the epiflora of two maerl beds in Galway Bay. Unpublished Ph.D. thesis, Galway: University College, Galway, Ireland

Maggs CA, Castilho R, Foltz D, Henzler C, Taimour J, Kelly J, Olsen J, Perez KE, Stam W, Vainola R, Viard F, Wares J (2008) Evaluating signatures of glacial refugia for North Atlantic benthic marine taxa. Ecology 89:S108-S122 
Maggs CA, Guiry MD (1988 '1987') Gelidiella calcicola sp. nov. (Rhodophyta) from the British Isles and northern France. Brit Phycol J XX:417-434

Maggs CA, Guiry MD (1989) A re-evaluation of the crustose red algal genus Cruoria and the family Cruoriaceae. Brit Phycol J $24: 253-269$

Martin S, Clavier J, Guarini J-M, Chauvaud L, Hily C, Grall J, Thouzeau G, Jean F, Richard J (2005) Comparison of Zostera marina and maerl community metabolism. Aquat Bot $83: 161-174$

Mendoza ML, Cabioch J (1998) Étude comparée de la reproduction de Phymatolithon calcareum (Pallas) Adey \& McKibbin et Lithothamnion corallioides (P. \& H. Crouan) P. \& H. Crouan (Corallinales, Rhodophyta), et reconsidérations sur la définition des genres. Canadian J Bot 76:1433-1445

Nelson WA (2009) Calcified macroalgae, critical to coastal ecosystems and vulnerable to change: a review. Mar Freshwater Res 60:787-801 
Noisette F, Duong G, Six C, Davoult D, Martin S (2013) Effects of elevated p $\mathrm{CO} 2$ on the metabolism of a temperate rhodolith Lithothamnion corallioides grown under different temperatures. J Phycol 49:746-757

OSPAR (2006) Case reports for the initial list of threatened species and/or declining species and habitats in the OSPAR region. OSPAR Commission

Otero-Schmitt, J. \& Pérez-Cirera, J.L. 2002. Infralittoral benthic biocenoses from northern Ría de Muros, Atlantic coast of northwest Spain. Botanica Marina 45:93-122

Pardo, C., López, L., Peña, V., Hernández-Kantún, J.J., Le Gall, L., Bárbara, I. \& Barreiro, L.. A multilocus species delimitation reveals a striking number of maërl species in the OSPAR region. Molecular Ecology Resources. Submitted.

Peña V. (2010) Estudio ficológico de los fondos de maerl y cascajo en el noroeste de la Península Ibérica. Tesis Doctoral, Universidade da Coruña.

Peña V, Adey WH, Riosmena-Rodriguez R, Yung M-Y, Choi H-G, Afonso-Carrillo J, Bárbara I (2011) Mesophyllum sphaericum sp. nov. (Corallinales, Rhodophyta): a new maërl 
-forming species from the northeast Atlantic. J Phycol $47: 911-27$

Peña V, Bárbara I (2006) Los fondos marinos de maërl del Parque Nacional de las Islas Atlánticas (Galicia, España): distribución, abundancia y flora asociada. NACC Nova Acta Cient Compostel Biol 15:7-25

Peña V, Bárbara I (2008a) Maërl community in the north-western Iberian peninsula: a review of floristic studies and long-term changes. Aquat Conserv 18:339-366

Peña V, Bárbara I (2008b) Biological importance of an Atlantic European maerl bed off Benencia Island (northwest Iberian Peninsula). Bot Mar 51:493-505

Peña V, Bárbara I (2009) Distribution of the Galician maerl beds and their shape classes (Atlantic Iberian Peninsula); proposal of areas in future conservation actions. Cah Biol Mar 50:353368

Peña V, Bárbara I (2010a) Seasonal patterns in the maërl community of shallow European Atlantic beds and their use as a baseline for monitoring studies. Eur J Phycol 45:327-43 
Peña V, Bárbara I (2010b) New records of crustose seaweeds associated with subtidal maë rl beds and gravel bottoms in Galicia (NW Spain). Bot Mar 53:41-61

Peña V, Bárbara I (2013) Non-coralline crustose algae associated with maerl beds in Portugal: a re-appraisal of their diversity in the Atlantic Iberian beds. Bot Mar In press.

Peña V, Bárbara I, Berecibar E, Santos R (2009) Present distribution of maërl beds in the Atlantic Iberian Peninsula. Museologia scientifica e Naturalistica, volumen speciale 6th Regional Symposium of the International Fossil Algae Association: 46.

Peña V, Hernandez-Kantun JJ, Grall J, Pardo C, Lopez L, Barbara I, Le Gall L, Barreiro R (2014) Detection of gametophytes in the maerl-forming species Phymatolithon calcareum (Melobesioideae, Corallinales) assessed by DNA barcoding. Cryptogamie algol. In Press.

Porzio L, Buia MC, Hall-Spencer JM (2011) Effects of ocean acidification on macroalgal communities. J Exp Mar Biol Ecol 400:278-287 
Potin P, Floch JY, Augris J, Cabioch J (1990) Annual growth rate of calcareous red alga Lithothamnion corallioides (Corallinales, Rhodophyta) in the Bay of Brest, France. Hydrobiologia 204/205:263-267

Ragazzola F, Foster LC, Form AU, Buscher J, Hansteen TH, Fietzke J (2013) Phenotypic plasticity of coralline algae in a High $\mathrm{CO}_{2}$ world. Ecol Evol 3:3436-3446

Rico JM, Guiry MD (1997) Life history and reproduction of Gelidium maggsiae sp. nov. (Rhodophyta, Gelidiales) from Ireland. Eur J Phycol 32:267-277

Rix LN, Burdett HL, Kamenos NA (2012) Irradiance-mediated dimethylsulphoniopropionate (DMSP) responses of coralline red algae. Est Coast Shelf Sci 96:268-72

Rosas-Alquicira EF, Riosmena-Rodriguez R, Cuto RP, Neto AI (2009) New additions to the Azorean algal flora, with ecological observations on rhodolith formations. Cah Biol Mar $50: 1-9$

Sauriau PG, Curti C, Jourde J, Aubert F, Cajeri P, Lavesque N, Dubois S, Lepareur F, Gouesbier C, Sauriau F, Sauriau M, Latry 
L, Leguay D, Robert S, Pineau P, Geairon P (2012) Le maerl algues corallinacees marines dans les Pertuis Charentais.

Annls Acad L Rochelle 10:281-300

Scottish MPA Project (2013) Assessment against the MPA Selection Guidelines. Loch Sween possible nature conservation MPA. http://www.snh.gov.uk/

Shultze K, Janke K, Krüb A, Weidemann W (1990) The macrofauna and macroflora associated with Laminaria digitata and L. hyperborea at the island of Helgoland (German Bight, North Sea). Helgoländer Meeresun 44:39-51

Sneli, JA. (1968) The Lithothamnion community in Nord-Möre, Norway with notes on the epifauna of Desmarestia viridis (Müller). Sarsia 31:69-74.

Steller DL, Riosmena-Rodriguez R, Foster MS (2007) Sampling and monitoring rhodolith beds. In: Rigby R, Iken K, Shirayama Y (ed) Handbook for Sampling Coastal Seagrasses and Macroalgae Community Biodiversity. Kyoto University Press, Kyoto, Japan

Strömfelt HFG (1886) Om algvegetationen vid Islands Kuster. pp. 189. Göteborg: Akademisk Afhandling 
Suneson S (1958) Lithothamnion calcareum vid svenska västkusten. Botaniska Notiser 111:197-199

Teichert S, Woelkerling W, Rüggeberg A, Wisshak M, Piepenburg D, Meyerhöfer M, Form A, Büdenbender J, Freiwald A (2012) Rhodolith beds (Corallinales, Rhodophyta) and their physical and biological environment at $80^{\circ} 31^{\prime} \mathrm{N}$ in Nordkappbukta (Nordaustlandet, Svalbard Archipelago, Norway). Phycologia 51:371-90

Teicherd S, Woelkerling W, Ruggeberg A, Wisshak M, Piepenburg D, Meyerhofer M, Form A, Freiwald A (2013) Artic rhodolith beds and their environmental controls (Spitsbergen, Norway). Facies DOI 10.1007/s10347-013-0372-2

Whelan PM, Cullinane JP (1985) The algal flora of a subtidal Zostera bed in Ventry Bay, southwest Ireland. Aquatic Botany $23: 41-51$

Wilson S, Blake C, Berges JA, Maggs CA (2004) Environmental tolerances of free-living coralline algae (maerl): implications for European marine conservation. Biol Cons 120:279-89 
Figure legends

Fig. 11.1. Distribution map and regions of interaction for unattached species of coralline algae in the North Atlantic. Eight species are represented; Lithothamnion glaciale and Phymatolithon calcareum are the most widespread. Interrupted lines indicate that the abundance is lower than in other areas represented. Arrows indicate possible direction of distribution (information requires future verification).

Fig. 11.2. North Atlantic beds of maerl and rhodoliths. a) Mannin Bay, Ireland, pale pink Lithophyllum fasciculatum, vivid red/pink Phymatolithon calcareum. b) Iceland dredge sample, Lithothamnion glaciale. c) Galicia, Spain, Mesophyllum sphaericum. d) Dog Island, Northern Labrador, Canada, mix of L. glaciale and L. tophiforme. 
Table 11.1. Rhodolith/maerl-forming species of coralline algae in the Northern Atlantic. Information on classification, type locality and distribution are presented. Unverified records are not included (see Pardo et al. submitted).

\begin{tabular}{lll}
\hline Order/Family/Species & Type locality & Distribution in the NE Atlantic \\
\hline Corallinales & \\
Corallinaceae & \\
Lithophylloideae & \\
Lithophyllum crouaniorum Foslie & Berwick-upon Tweed, Azores (as L. crouanii) ${ }^{1}$ \\
& Northumberland, Eng- \\
& land
\end{tabular}


Lithophyllum dentatum (Kützing) Naples, Italy $\quad$ Ireland $^{2}$

Foslie

Lithophyllum duckerae Woelker- Sicily, Italy Cornwall, England ${ }^{2}$

ling

Lithophyllum fasciculatum (La- Unknown* $\quad$ Ireland $^{2,3}$, France $^{4}$

marck) Foslie

Lithophyllum hibernicum Foslie Ballynakill Harbour, Ireland ${ }^{2}$

Galway, Ireland

Mastophoroideae 
42

Neogoniolithon brassica-florida

(Harvey) Setchell \& L.R. Ma-

son

Spongites fruticulosa Kützing

Hapalidiaceae

Melobesioideae

Leptophytum foecundum (Kjell-

man) Adey

Lithothamnion corallioides

(P.L.Crouan \& H.M.Crouan)

P.L.Crouan \& H.M.Crouan
Algoa Bay, Cape Azores ${ }^{1}$

Province, South Africa

Mediterranean Sea $\quad$ Madeira $^{5}$

Kara Sea, Russia. Newfoundland and Labrador Canada (Adey

pers. comm.)

Rade de Brest, Finis- $\quad$ France ${ }^{2,5,6}$, Ireland ${ }^{2,7,8}$, England ${ }^{2}$, Spain $^{9}$, Ma-

tère, France $\quad$ deira $^{5}$, Canary Islands ${ }^{10}$ 
Lithothamnion glaciale Kjellman Spitzbergen, Svalbard, North Atlantic Arctic and Subarctic ${ }^{11,12,13,14}$, Norway. $\quad$ Svalvard $^{15}$, Iceland ${ }^{16,17,18}$, Scandinavia ${ }^{19}$, Norway $^{17,20}$, Britain $^{2,21}$, Ireland ${ }^{2,21}$

Lithothamnion tophiforme (Esper)

Julianehaab, Green-

Canada $^{11,12}$, Greenland ${ }^{12}$, Iceland ${ }^{17,18,22}$, Nor-

Unger

land

way $^{12,17,20}$

Phymatolithon calcareum (Pallas) Falmouth, England

Sweden $^{23}$, Norway ${ }^{17}$, British Isles ${ }^{2}$, Ire-

Adey \& McKibbin

land $^{24,25,26}$, France $^{27,28,29}$, Spain $^{9,30}$, Azores $^{4}$

Phymatolithon purpureum

Mingant, Brest, France Norway $^{21}$, Britain and Ireland ${ }^{8}$

(P.L.Crouan \& H.M.Crouan)

Woelkerling \& L.M. Irvine 
44

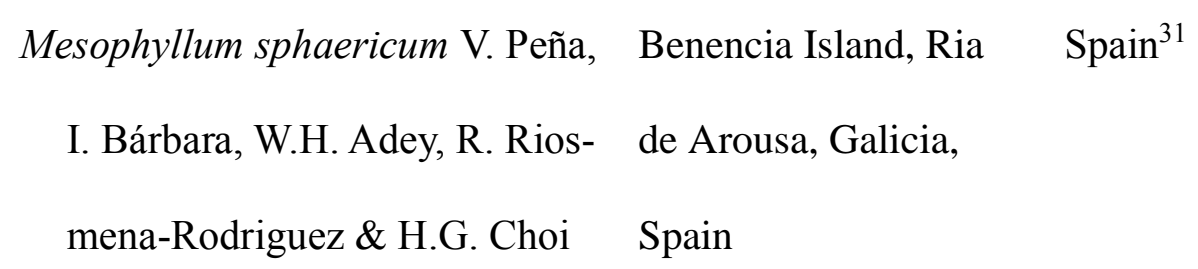

References: 1. Rosas-Alquicira et al. 2009; 2. Irvine \& Chamberlain 1994; 3. Foslie 1899; 4. Cabioch 1968; 5. Cabioch 1974; 6. Cabioch 1969; 7. Bosence 1980; 8. Blunden et al. 1981; 9. Peña \& Bárbara 2008b; 10. Alfonso-Carrillo \& Gil-Rodríguez 1982; 11. Kulka et al. 2004; 12. Adey et al. 2005; 13. Gagnon et al. 2012; 14. Kamenos et al. 2012; 15. Teichert et al. 2012; 16. Foslie 1905; 17. Adey 1971; 18. Gunnarsson 1977; 19. Athanasiadis 1996; 20. Foslie 1895; 21. Adey \& Adey 1973; 22. Strömfelt 1886; 23. Suneson 1958; 24.

Bosence 1976; 25. De Grave \& Whitaker 1999; 26. De Grave et al. 2000; 27. Lemoine 1910; 28. Mendoza \& Cabioch 1998; 29. Sauriau et al. 2012; 30. Adey \& McKibbin 1970; 31. Peña et al. 2011; 
